slack in the present system, for by now it is clear that the cost of accelerator physics is not so much the cost of building the machines but the cost of operating them. Where Britain is concerned, it would always be possible to arrange that the machines at Harwell and Daresbury should be shut down in phase with the start of operations at CERN some time in the late seventies.

In the circumstances, it will be no surprise if nuclear physicists take as their starting point for discussion of the project the opinion of the Swann report that "nuclear physies will wither away in the next 15 years" if Britain does not participate in the project. At the same time it is only proper to remember that nuclear physics is still very much the dominant partner in the pattern of expenditure of the Science Research Council. In 1966-67, for example, nuclear physies took 43 per cent of what there was to spend, compared with 25 per cent for astronomy, space and radio astronomy. The nuclear physicists may be threatened, but they are not yet the poor cousins. What has happened is worrying because it implies short commons for most people.

The decision also implies a strange relationship between the British Government and the supposedly independent bodies which are supposed to administer research spending. Nobody expects that the Science Research Council should be free to spend what is allocated to it entirely as it chooses, if only because current expenditure can imply larger commitments in the future. It is rare and even without precedent for its wishes to be overruled by fiat as on this occasion. (And has the Council for Scientific Policy on this occasion been properly consulted?) What has happened can only in the long run raise doubts about the respect which is accorded to the advisory committees which decide how funds like this should be spent.

\section{No British at CERN}

THE decision by the British Government not to take part in the project to build somewhere in Europe a $300 \mathrm{GeV}$ proton accelerator seems to have come as a great shock not only to the European Organization for Nuclear Research (CERN) which is organizing the project, but also to nuclear physicists in Britain. At present, feelings about the decision are running high. One British nuclear physicist, who said the decision represented a lack of respect for pure science, said, "It is worse than a crime-it is a blunder".

Announcing the decision in Geneva at a council meeting of CERN, Professor Brian Flowers, who as chairman of the Science Research Council was the British representative at the meeting, mentioned the factors influencing the decision. The Government was particularly concerned at the effect which participation in the project might have on the balance of resources between high energy physies and other scientific activities and had also to review the implications of the devaluation of sterling. In the light of its other commitments, the Government decided that expenditure involved in this very large project would not be justified.

The other members of CERN have taken the decision well, and it seems to have been generally accepted at
Geneva that the British decision is not a criticism of the scientific concept of the project. On the whole, the general feeling of the council meeting was that the accelerator should nevertheless be built. The scientific representatives were, it seems, virtually unanimous in the recommendation that Europe should go ahead without Britain; other representatives were more guarded in their initial reactions. CERN had alreadyrather wisely as it has turned out-considered the implications on the project if a single large contribution from one of the four countries, Britain, France, Germany and Italy, who together contribute 76 per cent of the present CERN budget, was not forthcoming. of the estimated cost, roughly half is for the machine itself and the rest for supporting facilities-experimental halls and so on. The British decision means the expected demand on the accelerator will be reduced, so that there is a possibility of achieving savings in the experimental facilities provided. If this is coupled with a modest reduction in the capabilities of the machine, something which no one wants to do but which may be necessary if the machine is to be built at all, European nuclear physicists are hoping the cost can still be kept within the price the countries remaining in the project are prepared to pay. Thought along these lines seems to present the best hope of saving the project.

What actually happens in the weeks to come depends of course on what France, Germany and Italy decide. All of them, before the announcement at Geneva, seem to have been favourably disposed towards the project. France has already formally declared its intention to join in, subject to certain safeguards (now of course it has a right to reconsider its decision), and Germany is on the point of making a decision, which it was widely suspected would be favourable. Italy has so far not made any formal announcement of its position.

\section{Clerks Wanted}

THE administration of the clerk's department of the House of Commons (the administrative assistants to the Select Committees of the House) desperately nceds both internal and external revisions, but the outlook is not good for any immediate reforms. 'This view emerged from evidence given by Sir Barnett Cocks, Clerk of the House of Commons, before the Select Committee on Science and Technology, Sub-Committee on Coastal Pollution, on May 21, now published (HMSO, 2s. 3d.). Sir Barnett stated that this year the Treasury rejected a long overdue proposal-approved by the Services Committce of the House of Commons-to increase from thirty-six to forty-six the number of clerks and to add five higher executive officers at an annual cost of $£ 40,000$; the Treasury's compromise solution was half the number requested, thereby saving $\mathfrak{f} 10,000$.

The present situation is, according to Sir Barnett, very near the breaking point. Until this year, only one new post had been established since 1961, yet the volume of work has more than doubled since that time-the number of questions increased from 12,200 to over 24,000 last year, the number of Bills being considered rose to eighty-one from twenty-seven in 1956-57, and the number of committees has grown from twenty-one in 1960-61 to seventy-six this session. This has meant that all the clerks must divide their time between at least two, and usually more, commit- 